\title{
フレッシュコンクリートの単位 STUDY ON DETERMINATION OF 水量試験に関する検討 WATER CONTENT OF FRESH CONCRETE
}

\author{
並木 哲一 $* 1$ \\ 久保田 浩 一*3 \\ 早川光敬 — $* 2$ \\ キーワード : \\ 単位水量, 試験方法, フレッシュコンクリート, 品質管理, 誤差 \\ Keywords : \\ Water content, Testing method, Fresh concrete, Quality controle, Errer
}

\section{Satoru NAMIKI $-* 1$ Hiroshi KUBOTA $-* 3$ \\ Mitsutaka HAYAKAWA — $* 2$}

Two types of the measuring method of water content in fresh concrete were tested in the laboratory and the field. Accuracy of microwave method was examined by comparing with that of the measuring apparent mass in water method. It became clear that water content in fresh concrete can be measured precisely with the microwave method if correction value with water cement ratio is get through the preliminary test.
1. はじめに

近年共同住宅の高層化が進み、それに伴い高強度材料の使用も増え てきている。

高強度材料の適用は、高層化を可能にするばかりでなく、大スパン 化や部材断面の減少による建物の軽量化·有効面積の拡大などの効果 も期待でき、高強度コンクリートは設計基準強度（以下 Fcの略す） $100 \mathrm{~N} / \mathrm{mm}^{2}$ のコンクリートが実用化されている1)。

このような高強度コンクリートでは今まで以上に品質管理が重要に なる。また、単位水量を管理することで、品質が安定し強度の変動が 小さくなることが確認されている2)。

単位水量測定方法として水中質量法は精度よく測定できることか ら、超高強度コンクリートの品質管理に用いている3)。しかし、水中 質量法は熟練した測定員が測定を行う必要が有る。そこで、測定員の 熟練度が比較的必要ないと思われる高周波加熱乾燥法の精度を確認 し、品質管理への適用性を検討した。

\section{2. 研究概要}

ここでは、水中質量法と高周波加熱乾燥法による単位水量測定方法 を取り上げ、測定精度の検討を行った。

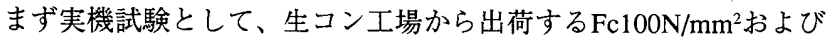
$\mathrm{Fc} 80 \mathrm{~N} / \mathrm{mm}^{2}$ のコンクリートについて、単位水量の変動を調査し、単位 水量試験方法の比較を行った。

次に、室内試験により単位水量試験方法の測定誤差の要因について 検討を行った。

\section{1 水中質量法}

\footnotetext{
*1 大成建設(侏)技術センター建築技術研究所材料研究室 課長

(テ245-0051 戸塚区名瀬町344-1)

*2 大成建設侏技術センター建築技術研究所材料研究室 副部長 - 工博

*3 大成建設侏技術センタ一建築技術研究所材料研究室 係長
}

コンクリートの水中質量と空中質量の差から単位水量を推定する。 試験手順は以下の通り。

1）コンクリート約 $2 \mathrm{~kg}$ を採取

2）コンクリートの空中質量を測定

3）水中にてコンクリート中の空気を追い出し、水中質量を測定

4) 粗骨材を洗い出し、粗骨材量を測定

5）空中質量と水中質量の差と、各材料の密度から単位水量を推定 する。

$$
\begin{gathered}
C o n_{v}=\frac{\operatorname{Con}_{s}-\operatorname{Con}_{w}}{\rho_{w}} \ldots \ldots \ldots \ldots \ldots . . .(1) \\
C o n_{v}=\frac{C s}{\rho_{c}}+\frac{S s}{\rho_{s}}+\frac{G s}{\rho_{G}}+\frac{W s}{\rho_{w}} \ldots \ldots \ldots \ldots . .(2)
\end{gathered}
$$

ここで、Con $\mathrm{v}$ : コンクリート試料体積 $\left(\mathrm{cm}^{3}\right) 、 \mathrm{Con}_{\mathrm{s}}$ : コンクリート 試料空中質量 $(\mathrm{g}) 、 \mathrm{Con}_{\mathrm{w}}$ : コンクリート試料水中質量 $(\mathrm{g}) 、$

$\rho_{\mathrm{w}}$ : 水温に対応する水の密度 $\left(\mathrm{g} / \mathrm{cm}^{3}\right) 、 \mathrm{Cs}$ : 試料中のセメント量 （g）、Ss：試料中の細骨材量（g）、Gs：試料中の粗骨材量 $(\mathrm{g}) 、 \mathrm{Ws}$ : 試料中の水量 $(\mathrm{g}) 、 \rho_{\mathrm{c}} 、 \rho_{s} 、 \rho_{\mathrm{G}}$ : セメント、細骨 材、粗骨材の密度 $\left(\mathrm{g} / \mathrm{cm}^{3}\right)$

\section{2 高周波加熱乾燥法}

ウェットスクリーニングによりコンクリートからモルタルを抽出 し、高周波加熱器（電子レンジ）により加熱乾燥を行い、単位水量を 推定する。測定手順は以下の通り。

業務用電子レンジ（電圧 $200 \mathrm{~V}$ 、出力 $1600 \mathrm{~W}$ ）を用いて測定を行 う。加熱時間は試料の最高温度が $200^{\circ} \mathrm{C}$ 以下 ${ }^{4)}$ となるように設定し た。試験手順を下記に示す。

${ }^{* 1}$ Senior Research Engineer, Taisei Corporation, Technology Center

*2 Deputy General Manager of Research Engineer, Taisei Corporation, Technology Center, Dr. Eng.

*3 Research Engineer, Taisei Corporation, Technology Center 
1）コンクリートを $5 \mathrm{~mm}$ るいに乗せ、バイブレータをかけながら、 ウェットスクリーニングを行う。

2) 試料容器（紙皿）を電子レンジで10秒間加熱する。

3）ウェットスクリーニングしたモルタルを試料容器（紙血）に約 400 $\mathrm{g}$ 採取して、モルタル質量を $0.1 \mathrm{~g}$ まで測定する。

4）試料を電子レンジで3分30秒間加熱する。

5）次式により、単位水量測定値を計算する。

$$
W=\frac{W b-W a}{W b-W c} \times(W+C+S)-\frac{P}{100+P} \times S+A d \times \frac{m}{100}
$$

$\mathrm{W}$ : 単位水量測定値 $\left(\mathrm{kg} / \mathrm{m}^{3}\right)$

$\mathrm{Wa}$ : 容器質量 $(\mathrm{g})$

$\mathrm{Wb}$ : 乾燥前モルタル質量十容器質量 $(\mathrm{g})$

$\mathrm{Wc}$ : 乾燥後モルタル質量十容器質量 $(\mathrm{g})$

$\mathrm{W}$ : 計画単位水量 $\left(\mathrm{kg} / \mathrm{m}^{3}\right)$

$\mathrm{C}$ ：計画単位セメント量 $\left(\mathrm{kg} / \mathrm{m}^{3}\right)$

$\mathrm{S}$ : 計画単位細骨材量 $\left(\mathrm{kg} / \mathrm{m}^{3}\right)$

$\mathrm{P}$ : 細骨材吸水率 $(\%)$

Ad：計画単位混和剤量 $\left(\mathrm{kg} / \mathrm{m}^{3}\right)$

$\mathrm{m}:$ 混和剤固形分量 $(\%)$

\section{3. 生コン工場での比較試験}

コンクリートは川崎市に建設中の R C 高層マンション D工事に打設 される $\mathrm{Fc} 100 \mathrm{~N} / \mathrm{mm}^{2}$ および $\mathrm{Fc} 80 \mathrm{~N} / \mathrm{mm}^{2}$ の高強度コンクリートである。 使用材料抒よび調合を表 1,2 に示す。測定は、Fc100N/mm²は延べ5 日、Fc80N/mm²は6日間について、出荷する全ての生コン車からコン クリートをサンプリングして、単位水量を測定した。

単位水量の試験結果を図 $1,2 に 、$ 各試験方法の測定結果の関係を図 3,4 に示す。単位水量管理の上限值を $165 \mathrm{~kg} / \mathrm{m}^{3}$ としたが、実工事では 調合值の $155 \mathrm{~kg} / \mathrm{m}^{3}$ を超えることを恐れたために、全体に単位水量が低 めの值となった。

試験結果から、高周波加熱乾燥法は水中質量法と比較すると、全体 的に Fc100N/mm 2 の調合では少なめであるが、Fc80N/mm²の調合では

多く測定していることが分かった。

また、日内の測定值の変動傾向は、高周波加熱乾燥法と水中質量法 は、調合に関係なく測定日によってほぼ同じ場合と、ずれが生じる場 合があることが分かった。

このことから加熱乾燥法の絶対值のずれを補正する必要があること がわかる。これらの単位水量測定結果のずれは、測定方法そのものの 誤差と、ウェットスクリーニングによる誤差が含まれていると考えら

\section{表1 使用材料}

\begin{tabular}{|c|c|}
\hline 結合材 & 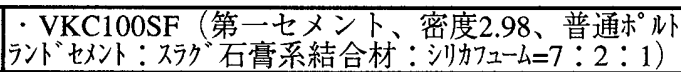 \\
\hline 細骨材 & ·君津産山砂（密度2.61） \\
\hline 粗骨材 & ·大月産砕石（安山岩）（密度2.65、実績率60\%） \\
\hline 混和剂 & ・高性能AE減水剂 (ポリカルボン酸系) \\
\hline
\end{tabular}

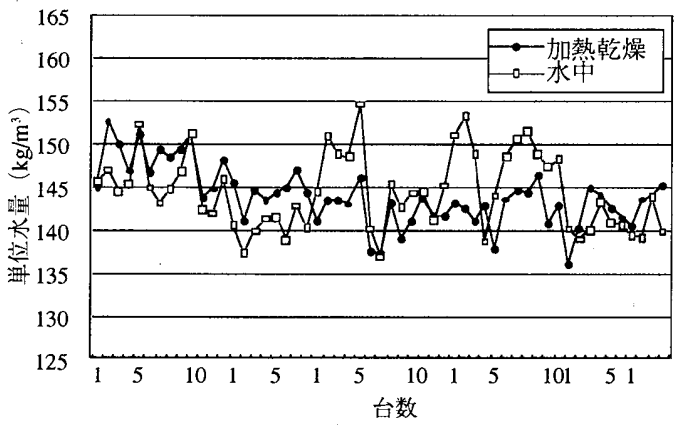

図1 単位水量測定結果 $(\mathrm{Fc} 100)$

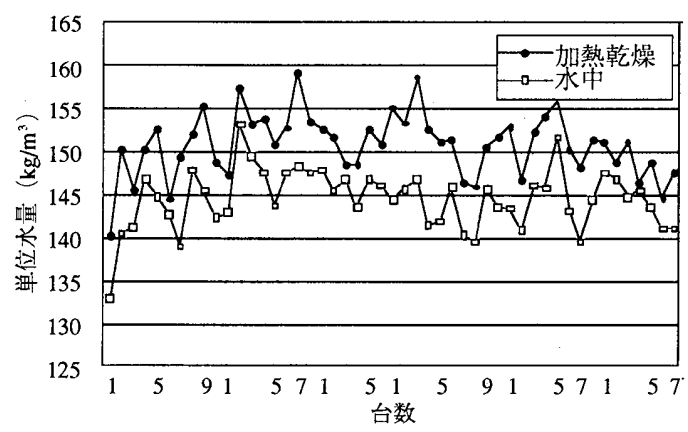

図2 単位水量測定結果 (Fc80)

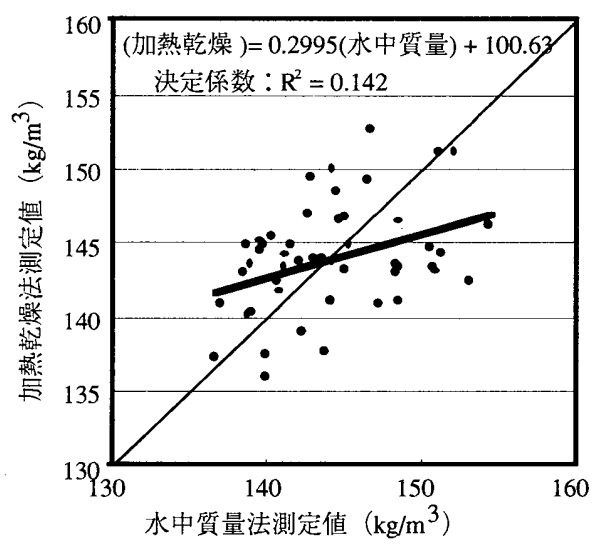

図3 水中質量法と加熱乾燥法の関係（Fc100）

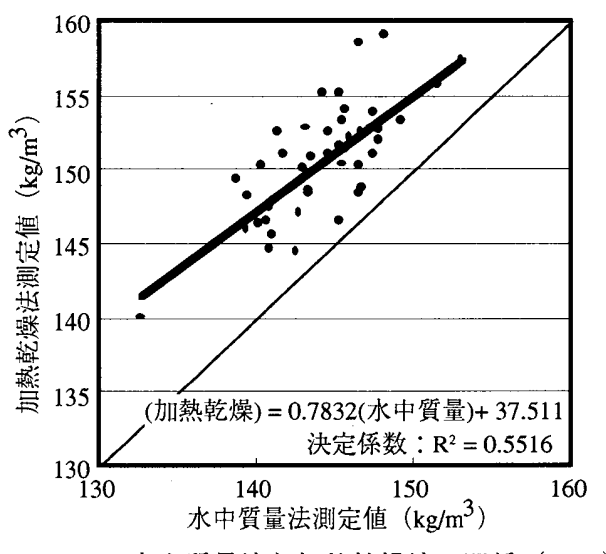

図4 水中質量法と加熱乾燥法の関係（Fc80）

表2 調合

\begin{tabular}{|c|c|c|c|c|c|c|}
\hline \multirow{2}{*}{$\begin{array}{c}\mathrm{Fc} \\
\left(\mathrm{N} / \mathrm{mm}^{2}\right)\end{array}$} & \multirow{2}{*}{$\begin{array}{c}\mathrm{W} / \mathrm{B} \\
(\%)\end{array}$} & \multicolumn{5}{|c|}{ 単位量 $\left(\mathrm{kg} / \mathrm{m}^{3}\right)$} \\
\hline & & 水 & 結合材 & 細骨材 & 粗骨材 & 高性能 A E 減水剂 \\
\hline 100 & 22.5 & 155 & 689 & 692 & 871 & 18.6 \\
\hline 80 & 29.5 & 155 & 526 & 835 & 871 & 11.6 \\
\hline
\end{tabular}


れる。ウェットスクリーニングによる䛊差の原因としては、調合によ りウェットスクリーニングで採取するモルタル中の単位水量が変化す ること、および、調合の違いだけでなく、同一調合でも単位水量の差 によりモルタルの粘性が異なることが考えられる。

\section{4. 室内試験}

\section{1 目的}

練り混ぜたモルタルおよび、コンクリートからウェットスクリーニ ングにより取り出したモルタルを用いて高周波加熱乾燥法で単位水量 試験を実施して、試験方法固有の誤差とウェットスクリーニングによ る誤差の検討を行うとともに、ウェットスクリーニングによる補正方 法の検討を行った。

\section{2 使用材料および調合}

使用した細骨材および粗骨材は、生コン工場での比較試験で使用し たものと同一とし、モルタル調合を表3に、コンクリート調合を表4

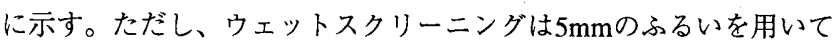
行うことから、骨材粒度分布の影響を排除するために、細骨材は $5 \mathrm{~mm}$ 上をカットし、粗骨材は $5 \mathrm{~mm}$ 下をカットして使用した。

\section{3 試験方法}

\section{1）モルタル試験}

練り混ぜはモルタルミキサを使用し、練り量は3リットルとした。練上 がり後直ちに、高周波加熱乾燥法で単位水量測定を行った。

2) コンクリート試験

練り混ぜは強制練りミキサを使用し、モルタル先練り後、粗骨材を 投入した。練り量は20リッルとした。

練上がり後、ウェットスクリーニングを行い、取り出したモルタル について、高周波加熱乾燥法で単位水量測定を行った。

\section{4 測定結果}

単位水量の測定結果を表5に示す。

\section{1）モルタル試験結果}

練混ぜ時に材料を採取して表面水率を測定し、正確な実施調合を求 めて、測定結果と比較すると水量はほほ一致しているが、水結合材比 が高い調合では水量を少なく推定する傾向が若干認められた。試験全 体での測定値の標準偏差は $\sigma=2.5 \mathrm{~kg} / \mathrm{m}^{3}$ であり、信頼限界 $95 \%(1.96$ б）でも、 $\pm 4.8 \mathrm{~kg} / \mathrm{m}^{3}$ の推定誤差であることがわかった。

2）コンクリート試験

測定結果は、実施調合と比較すると水結合材比が高い調合では水量 を少なく推定し、水結合材比が低い調合では水量を多く推定している ことが分かった。図5の結合材水比の推定值からも結合材水比の影響 を受けていることが分る。

モルタル試験の結果から、試験法固有の誤差は小さいと考えられる ことから、このコンクリートでの誤差はウェットスクリーニング時に 粗骨材に付着して残るモルタルとふるいから落下寸るモルタルの品質 の差と考えられる。図5を見ると、結合材水比の測定結果と実施值は 直線関係にあることから、結合材水比の一次式を補正値として用いれ ば誤差の補正が可能である。図5より求めた回帰式を元に、結合材水 比の違いによる補正值を求め、単位水量を推定した結果を表 5 に示 す。

\section{5. 室内試験による誤差の検討}

表3 モルタルの調合

\begin{tabular}{|c|c|c|c|c|c|}
\hline \multirow{2}{*}{ No. } & \multirow{2}{*}{$\mathrm{W} / \mathrm{B}$} & \multirow{2}{*}{$\begin{array}{l}\text { 空気量 } \\
\text { \% }\end{array}$} & \multicolumn{3}{|c|}{ 単位量 $\left(\mathrm{kg} / \mathrm{m}^{3}\right)$} \\
\hline & & & 水 & 結合材 & 細骨材 \\
\hline 1 & 20.0 & \multirow{4}{*}{2.0} & 231 & 1157 & 932 \\
\hline 2 & 22.5 & & 231 & 1028 & 104 \\
\hline 3 & 26.0 & & 231 & 890 & 1162 \\
\hline 4 & 29.5 & & 231 & 784 & 1253 \\
\hline
\end{tabular}

表4 コンクリートの調合

\begin{tabular}{|c|c|c|c|c|c|c|c|}
\hline \multirow{2}{*}{ No. } & \multirow{2}{*}{$\begin{array}{c}\mathrm{Fc} \\
\left(\mathrm{N} / \mathrm{mm}^{2}\right)\end{array}$} & \multirow{2}{*}{$\mathrm{W} / \mathrm{B}$} & \multirow{2}{*}{$\begin{array}{l}\text { 空気量 } \\
(\%)\end{array}$} & \multicolumn{4}{|c|}{ 単位量 $\left(\mathrm{kg} / \mathrm{m}^{3}\right)$} \\
\hline & & & & 水 & 結合材 & 細骨材 & 粗骨材 \\
\hline 1 & 110 & 20.0 & \multirow{4}{*}{2.0} & 155 & 775 & 624 & 868 \\
\hline 2 & 100 & 22.5 & & 155 & 689 & 698 & 868 \\
\hline 3 & 90 & 26.0 & & 155 & 596 & 778 & 868 \\
\hline 4 & 80 & 29.5 & & 155 & 525 & 839 & 868 \\
\hline
\end{tabular}

表5 単位水量測定結果

\begin{tabular}{|c|c|c|c|c|c|c|c|}
\hline \multirow[b]{2}{*}{$\mathrm{W} / \mathrm{B}$} & \multicolumn{3}{|c|}{ モルタル単位水量 $\left(\mathrm{kg} / \mathrm{m}^{3}\right)$} & \multicolumn{4}{|c|}{ コンクリート単位水量 $\left(\mathrm{kg} / \mathrm{m}^{3}\right)$} \\
\hline & 実施 & 測定 & 測定-実施 & 実施 & 測定 & 測定-実施 & 補正 \\
\hline 20.0 & 231.0 & 232.9 & 1.9 & 150.1 & 156.4 & 6.3 & 151.9 \\
\hline 22.5 & 230.9 & 230.5 & -0.4 & 150.0 & 149.1 & -0.9 & 147.3 \\
\hline 26.0 & 230.9 & 230.2 & -0.7 & 150.0 & 146.1 & -3.9 & 149.1 \\
\hline 29.5 & 230.9 & 228.8 & -2.1 & 150.3 & 143.8 & -6.5 & 152.2 \\
\hline
\end{tabular}

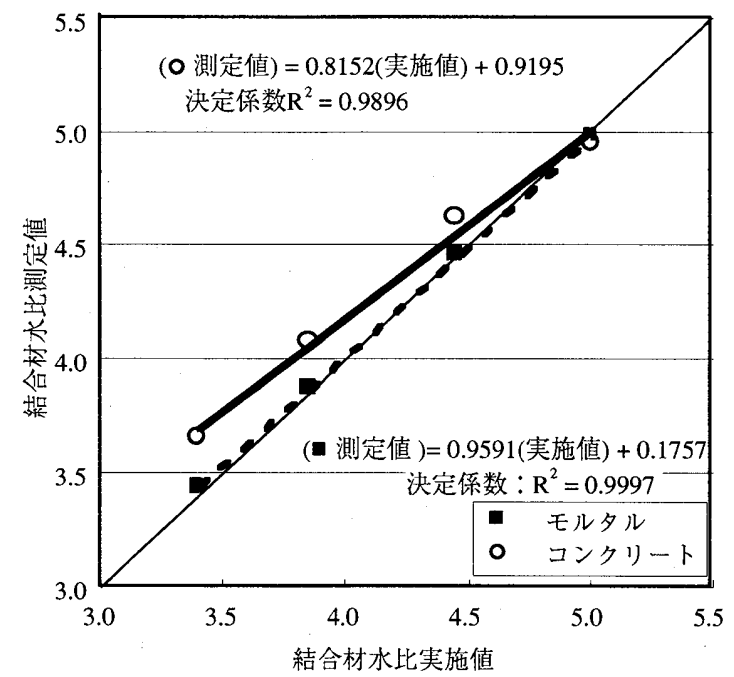

図5 セメント水比での比較

\section{1 目的}

単位水量の測定誤差とは、基準值に対するばらつきであるが、ウ エットスクリーニングに起因する基準值に対するずれは、「4.4測定 結果」に示したような回帰式により補正できることから、ここでは、 補正後の䛊差について検討する。

\section{2 誤差の検討方法}

高周波加熱乾燥法で予想される種々の誤差要因と誤差条件を設定し て、試験誤差の計算上での検討を行う。ここでは、材料品質が変動す る生コン工場のコンクリートについて、事前に把握した材料品質の数 值を用いて単位水量推定試験を受入管理として長期間行う場合につい ての検討を行う。 
表6＼cjkstart誤差要因と誤差条件

\begin{tabular}{|c|c|c|c|c|c|c|c|c|c|c|c|}
\hline $\begin{array}{c}\text { 材料試験の } \\
\text { 測定誤差 }\end{array}$ & \multicolumn{3}{|c|}{ 単位水量試験の測定誤差 } & \multicolumn{3}{|c|}{ 材料の計量誤差（\%） } & \multicolumn{5}{|c|}{ ウェットスクリーニング時の材料誤差 } \\
\hline \multirow{2}{*}{$\begin{array}{c}\text { 細骨材吸水 } \\
\text { 率 }(\%)\end{array}$} & \multirow[b]{2}{*}{$\begin{array}{l}\text { 秤 } \\
(\mathrm{g})\end{array}$} & \multicolumn{2}{|c|}{ 骨材の表面水率（\%） } & \multirow[b]{2}{*}{ 水 } & \multirow[b]{2}{*}{ セメント } & \multirow[b]{2}{*}{ 細骨材 } & \multirow{2}{*}{$\begin{array}{c}\text { 粗骨材吸水 } \\
\text { 率 }(\%)\end{array}$} & \multicolumn{2}{|c|}{ 骨材の粒度（\%） } & \multirow{2}{*}{$\begin{array}{c}\text { 粗骨材の州 } \\
シ 7^{\circ} リ シ ク ゙ ~ \\
(\%)\end{array}$} & \multirow{2}{*}{$\begin{array}{c}\text { 粗骨材の } \\
\text { 計量誤差 } \\
(\%)\end{array}$} \\
\hline & & 細骨材 & 粗骨材 & & & & & 細骨材 & 粗骨材 & & \\
\hline \pm 0.2 & \pm 0.2 & \pm 1 & \pm 0.5 & \pm 1 & \pm 1 & \pm 3 & \pm 0.15 & \pm 2 & \pm 3.5 & \pm 10 & \pm 3 \\
\hline
\end{tabular}

想定される誤差としては、a.材料品質試験の測定誤差、b.単位水量 試験の測定誤差、c.コンクリート製造時の材料の計量誤差、d. $5 \mathrm{~mm}$ ふ るいを用いたウェットスクリーニング時の材料の誤差がある。表6に それらの誤差要因と予想される誤差範囲を示す5)。

誤差は、単位水量推定計算式に表6の誤差を入れて単位水量をそれ ぞれ求めて推定誤差を算出した。個々の変動要因による単位水量の推 定誤差を $3 \sigma$ として (4) 式により累積して求めた。

$$
\sigma=\left(\sigma_{1}{ }^{2}+\sigma_{2}{ }^{2}+\sigma_{3}{ }^{2}+\cdots \cdots+\sigma_{n}{ }^{2}\right)^{0.5} \cdots \cdots \cdots \cdots(4)
$$

また、受入管理として単位水量の測定を行う場合、生コン工場での 材料の品質変動による誤差が加わる。表7に誤差条件を示す。 従って（4）式で求めた誤差と材料の品質変動による誤差を累積した 物を品質管理試験としての全体誤差とした。

\section{3 検討結果}

材料の品質変動による単位水量推定値の誤差を累積した場合の計算 結果を表8に示す。表8には、水中質量法について同様な検討を行った 結果についても記載した5)。

この結果から、事前の材料試験デー夕を用いた単位水量推定試験を 長期間行った場合には、材料の品質変動を含む品管試験としての全体 誤差は、95\%信頼限界 $(1.96 \sigma)$ で土11.3〜 $16.1 \mathrm{~kg} / \mathrm{m}^{3}$ となった。

したがって、あらかじめ結合材水比を変えた調合で3点以上の試験 練りを行って単位水量試験を実施し、補正值式を求めた上で測定する ことにより、水中質量法の誤差 $\left( \pm 10.5 \sim 13.0 \mathrm{~kg} / \mathrm{m}^{3}\right)$ と比較すると、 高強度コンクリートではほほ同じ程度の誤差であるが、普通強度コン クリートでは誤差が大きいことが分かった。

6. まとめ

受入検査としての 2 種類の単位水量試験について、その精度と実工 事での管理方法について検討を行った結果、以下の事が明らかとなっ た。

1）実機試験の結果、水中質量法と高周波加熱法では、調合により単
表7 材料の品質変動の設定值

\begin{tabular}{|c|c|c|c|}
\hline \multicolumn{2}{|c|}{ 吸水率 (\%) } & \multicolumn{2}{c|}{ 骨材の粒度 (\%) } \\
\hline 細骨材 & 粗骨材 & 細骨材 & 粗骨材 \\
\hline \pm 0.6 & \pm 0.3 & \pm 5 & \pm 10 \\
\hline
\end{tabular}

位水量測定結果に差がある。

2）水中質量法と高周波加熱法の測定結果の差は、主にウェットスク リーニングの影響と考えられ、調合によりその影響が異なる。

3）高周波加熱乾燥法をコンクリートの品質管理に適用するには、 $\mathrm{W} / \mathrm{C}$ を3点程度変化させたコンクリートについて、単位水量試験 を行い、補正值式を求める必要がある。

4）上記補正值を求めることで、高強度コンクリートでは水中質量法 と同程度の精度で単位水量測定が可能である。

\section{参考文献}

1）並木哲・沢井布兆・黒羽健嗣 - 原孝文：Fc1000 $\mathrm{kgf} / \mathrm{cm}^{2}$ の高強度コ ンクリートを用いた超高層建築物の施工、コンクリート工学、 Vol.37,No.3,pp.35 38,1999.3

2）並木哲：CFT構造および高層RC造における品質管理の現状、コン クリート工学、Vol.39,No.5,pp.52 55,2001.5

3）陣内浩 - 黒羽健嗣・他：設計基準強度 $1000 \mathrm{kgf} / \mathrm{cm}^{2}$ の高強度コンク リートを用いた超高層建築物の施工、日本建築学会技術報告集、第9 号,pp.7 12,1999.12

4）橋本真幸 - 猪熊洋典 - 伊興田直行：高周波加熱乾燥法によるフ レッシュコンクリートの簡易単位水量推定試験に関する研究、第11回 生コン技術大会研究発表論文集、pp69～74、2001

5）丸嶋紀夫、黒羽健嗣、並木哲、久保田浩：水中質量法による レッシュコンクリートの単位水量試験方法、コンクリート工学年次論 文報告集、Vol.20,No.2,pp.313 318,1998

表8 単位水量測定結果 (単位 $: \mathrm{kg} / \mathrm{m}^{3}$ )

\begin{tabular}{|c|c|c|c|c|c|c|c|c|c|c|}
\hline \multirow{2}{*}{ 測定方法 } & \multirow[b]{2}{*}{ 調合 } & \multicolumn{3}{|c|}{ 材料の品質変動による誤差 } & \multicolumn{3}{|c|}{ 材料の品質変動がない場合の総合誤差 } & \multicolumn{3}{|c|}{ 品管試験としての全体誤差 } \\
\hline & & $\sigma$ & $1.96 \sigma$ & $3 \sigma$ & $\bar{\sigma}$ & $1.96 \sigma$ & $3 \sigma$ & $\sigma$ & $1.96 \sigma$ & $3 \sigma$ \\
\hline \multirow{4}{*}{ 加熱乾燥法 } & Fc60 & 4.37 & 8.57 & 13.12 & 3.8 & 7.4 & 11.4 & 5.8 & 11.3 & 17.4 \\
\hline & $\mathrm{Fc} 48$ & 4.79 & 9.38 & 14.36 & 3.9 & 7.6 & 11.7 & 6.2 & 12.1 & 18.5 \\
\hline & Fc36 & 5.53 & 10.84 & 16.59 & 4.1 & 8.0 & 12.2 & 6.9 & 13.4 & 20.6 \\
\hline & Fc21 & 6.94 & 13.61 & 20.83 & 4.4 & 8.7 & 13.3 & 8.2 & 16.1 & 24.7 \\
\hline \multirow{4}{*}{ 水中質量法 } & Fc60 & 4.89 & 9.59 & 14.68 & 2.2 & 4.3 & 6.6 & 5.4 & 10.5 & 16.1 \\
\hline & $\mathrm{Fc} 48$ & 5.14 & 10.08 & 15.43 & 2.3 & 4.6 & 7.0 & 5.7 & 11.1 & 16.9 \\
\hline & $\mathrm{Fc} 36$ & 5.54 & 10.85 & 46.61 & 2.5 & 4.9 & 7.4 & 6.1 & 11.9 & 18.2 \\
\hline & Fc21 & 6.01 & 11.79 & 18.04 & 2.8 & 5.5 & 8.4 & 6.6 & 13.0 & 19.0 \\
\hline
\end{tabular}

